\title{
12. How Violent Victimisation Affects Moral Cognitions, Moral Emotions and Moral Motivation
}

\author{
Bettina Doering, Dirk Baier
}

\subsection{Theoretical background}

A key focus of criminological research is to explain delinquent behaviour. Such behaviour constitutes a deviation from the norm, i.e. it breaches the law. The law is, to a great extent, an expression of social consensus on tolerable and intolerable behaviour. That consensus in turn is based on shared moral values. Laws that prevail without any moral reference can be perceived as arbitrary and are thus often ignored. People whose personal moral values mirror those on which laws are based tend to adhere to those laws. People's moral values should thus be a key influencing factor of delinquent behaviour.

Surprisingly, there are only few criminological research approaches that have focused on the link between morality and delinquent behaviour. One exception is the work of Wikström on the Situational Action Theory of Crime Causation (cf. Wikström 2009, Wikström et al. 2010, Wikström/ Treiber 2009). Here, the assumption is that all criminal behaviour is based on morality. People engage in criminal activity because they perceive criminal behaviour as an action alternative and choose it as one of many possible types of behaviour. This two-step process is driven by a person's propensity and by the criminogenic factors (exposure) of a given situation. Propensity depends on a person's moral standards and values and their self-control, and also on the interplay between the two. High moral standards and values result in certain alternative courses of action being left out of consideration. People with high morality do not seek to solve interpersonal conflict with violence; rather, when attempting to mediate in a conflict situation, they choose other behaviours such as talking, withdrawing, and so on. This theory is supported by empirical analysis. The 'propensity' factor, meaning low morality and self-control, significantly increases criminal behaviour (cf. Wikström 2009). Other empirical studies also confirm that the higher a person's moral standards and values, the 
lower their risk of delinquent behaviour (cf. Barriga et al. 2001, Krettenauer/Eichler 2006, Murray-Close et al. 2006, Stams et al. 2006).

One key problem in existing studies is their vague definition of morality. Wikström (2006) places moral standards and values on an equal footing with abiding by the law. This is particularly evident when operationalising morality: Svensson et al. (2001, p. 741) ask whether it is right to do something illegal as long as one is not caught. Here, an illegal act is evaluated on the basis of whether the perpetrator gets away with it. It is not the moral standpoint but the fear of being caught that is operationalised. Moral standards and values describe, by way of contrast, underlying principles which have universal, categorical, non-partisan application (Celikates/Gosepath 2009, Nunner-Winkler 1991), and which although partly enshrined in law must still be seen as separate from the legal system.

To conduct empirical analysis of the role of morality in explaining delinquent behaviour and the socialisation factors connected with morality, it therefore appears necessary to define morality in a way that goes beyond law abidance (cf. Doering 2013, 2013a). In general, individual morality is to be seen as the degree of abidance with fundamental principles that demonstrate the stated characteristics. This abidance can be divided into three components (cf. Rest 1983): the cognitive, the emotional and the motivational. With regard to the cognitive component, the work of Kohlberg in particular analysed people's ability to exercise moral judgement. Barriga et al. (2001) further developed this research tradition, and also developed a measure for standardised surveys. In contrast with Kohlberg's Kantian approach, Barriga et al. (2001) look at moral traits, thus taking a more virtue-ethics position as used by Aristotle. When it comes to an individual's sense of self, these traits are important in different ways. The more important they are thought to be - especially when compared to non-moral traits - the more embedded moral principles are in the cognitive structure of a person.

The emotional component is, for example, emphasised in the works of Braithwaite (1989), who looks at the role of feelings of shame. Breaking the rules can evoke such feelings. However, Braithwaite's focus lies primarily on the sanctions involved in such breaches rather than the factors that tend to prevent them. Krettenauer and Eichler (2006) also look at moral emotions. Their findings show that adolescents who anticipate feelings of guilt or shame after breaking the rules demonstrate less delinquency. These findings may show that the adolescents concerned demonstrate greater feelings of empathy. Empathy is discussed as a key influencing 
factor of delinquency (cf. Hosser/Beckurts 2005), and is defined as "an affective response that stems from the apprehension or comprehension of another's emotional state or condition and is similar to what the other person is feeling or would be expected to feel" (Eisenberg 2002, p. 135). Acts of violence are thus prevented by empathy because it is anticipated that there could be serious consequences for the other party.

A further decisive component of morality agreed upon in current research alongside these first two components is moral motivation (Pratt et al. 2003). According to Nunner-Winkler (2008, p. 103f), moral motivation comprises a person's willingness to accept the consequences of doing what they believe to be right. Morally motivated individuals accept that moral principles take priority over personal needs. Less morally motivated people tend to put their personal needs first, making them more likely to adopt delinquent behaviour that can bring them short-term benefits. Unlike the cognitive and emotional components, moral motivation thus involves the degree to which moral knowledge and moral emotion are perceived as binding.

Up to now, the relationship between the three components of moral standards and values has not been sufficiently studied, hence it must be assumed that they are similar in serving as behavioural indicators and are similarly influenced by socialisation factors. Independent of the concrete relationship between the components of morality, it can be helpful in empirical analysis of the causes and consequences to draw on a more nuanced concept of morality.

As with most personality traits, the socialisation factors of individual morality are many and varied. The role of victimisation experience is a case in point. Focus is placed on this factor because research has shown victimisation to be a drastic, life-shaping experience. In an American study, Kahn (1984) showed that victimisation experience goes hand in hand with depression, anxiety, feelings of shame, and a range of other psychological problems. Experience of serious victimisation can also trigger post-traumatic stress disorder (cf. North et al. 1994). Apart from internalising behaviours, victims can also display externalising behavioural disorders. Various authors point to the fact that people with experience of victimisation display aggressive behaviour in inappropriate situations because they chronically accuse the other people involved of having negative intentions and can only react to them in an aggressive way (Dodge 1993, Staub 1998). Findings on intrafamilial violence showing that victims of 
this violence have a greater risk of violent behaviour in adolescence underline the link to externalising disorders (cf. Baier/Pfeiffer 2011).

One theoretical explanatory model for the stated relationships is provided by the social information processing model (Crick/Dodge 1994), which attempts to explain people's ability to adjust socially and to stand out. When one person meets another, these basic prerequisites shape the interaction between them. On the one hand, these prerequisites are biological abilities; while on the other, they constitute what is known as the 'data base' of past experience, meaning specific memories which, among other things, dictate social skills and shape social models. The data base is used in each step of the social information process. Crick and Dodge (1994) describe six different sub-processes of information processing. In the first two (encoding and interpretation), people selectively acknowledge individual situational stimuli and begin to construe a mental representation of a situation. Steps three and four (classification of cues and response access or construction) involve target selection and construction of a potential response. Choice of behaviour occurs in step five (response decision), while the chosen behaviour is executed in step six (behavioural enactment). The experiences stored in the data base influence each and every step of the process.

As already shown, people with aggressive or delinquent behaviour display a cronic 'hostile attribution error' (Dodge 1980) and thus a general tendency to accuse others more frequently of having negative intentions. Apart from the effects on encoding and interpretation of situational stimuli, aggressive models contained in the data base also affect other processes. For example, it has been shown that aggressive behaviour is regarded as positive because it is seen to promise success. As a result, people with such learning experiences also tend more frequently to aggressive behaviour (Perry et al. 1986). Also, the experiences of aggressive people limit their behavioural spectrum to the extent that fewer socially acceptable behavioural alternatives are available to them (Slaby/Guerra 1988).

Experience of violence can alter the data base as described. Dodge et al. (1990) note that, among other things, experience of abuse can result in the social environment being perceived as dangerous and threatening. Under learning theory, it can also be assumed that the experience of violence leads to modelling. From parental example, for instance, a child or adolescent learns that aggression and violence can be used to resolve conflicts as well as to achieve personal goals and protect personal interests. Thus, aggressive schemas, content and emotions are all stored in the data base. In 
the past, such influence of violent victimisation has mainly been substantiated on the basis of domestic violence; for children and adolescents, however, it is also just as plausible that experience of violence outside the family leads to negative personality traits, thus hindering the development of positive traits. It is also to be assumed that frequent experience of violence or of severe violent victimisation is particularly impactful. Baier et al. (2011, p. 95ff) show, for example, that people with experience of repeated victimisation display an especially intense fear of crime. It is important to note here that the effect of repeated victimisation cannot be verified with the data provided in the following because repeated violent victimisation occurs too seldom in the sample. Only the effects of severity of victimisation can be verified. That an effect is assumed can be justified in that such offences are thought to be particularly salient and thus of particular importance.

Few empirical studies have been conducted on how violent victimisation influences a person's morality. Studies only support a negative relationship for the emotional component: Experience of violence reduces empathy (Malti et al. 2010, Wilmers et al. 2002, p. $244 \mathrm{ff}$ ). In such cases, a circular process must be assumed: Victimised children and adolescents find it difficult to put themselves in their opposite number's place. They react by rejecting offers of contact, which in turn results in them accusing the others of being unfriendly. Thus, contact, which is central to the exercise of perspective-taking and empathy (Arsenio/Lemerise 2001), does not occur. Although these relationships can only be confirmed for empathy, it is assumed here that the other components of moral standards and values are also less well developed in individuals who have experienced violence. When analysing this issue, focus is placed on adolescents who are in the identity-building phase of their psychological development.

The influencing factors of morality and any delinquency-reducing effect of moral identity should apply equally to different groups of individuals. Males and females should differ on this score just as little as natives and foreigners or highly educated and poorly educated individuals. Especially in respect of gender, a range of studies show significant differences of degree, with girls seen as having higher morality (especially in teenage years), committing fewer violent acts and less frequently becoming victims of violence (see Doering 2013, 2013a; Baier 2011). Experience of violence, however, should be equally as bad for the moral development of girls as for that of boys. 
Based on the theoretical assumptions and empirical findings presented so far, a number of hypotheses can be formulated for the analyses that follow:

- Hypothesis 1: Victims of violence demonstrate lower morality than non-victims.

- Hypothesis 1a: Experience of serious violence significantly reduces morality in comparison to experience of mild violence.

- Hypothesis 1b: Boys and girls do not differ in respect of the stated relationships.

- Hypothesis 2: Adolescents with high morality commit fewer acts of violence than those with lower morality.

- Hypothesis 2a: Morality mediates the relationship between victimisation and violent delinquency.

\subsection{Methodology}

\subsubsection{Sample}

To test the hypotheses, a school survey of ninth graders was conducted in May and June 2010 in the district of Emsland (cf. Doering/Baier 2011). Emsland is located in the northern German State of Lower Saxony, and displays a number of interesting characteristics: It is a largely rural area, where unemployment and receipt of welfare benefit is significantly lower than in other parts of the country or the region. Almost three-quarters of adolescents belong to the Catholic Church, while the national average is less than half. The number of adolescents who have experienced parental separation is also lower than in other regions. The conditions for growing up in this district are thus seen as more intact than in other parts of Germany.

A representative, standardised, administered school survey was conducted, using a written questionnaire which was given out to the various classes during lessons. 4,014 pupils were taught in 177 ninth grade classes in Emsland during school year 2009/2010. The aim was to involve all classes and all pupils in the survey. After some schools refused to take part as well as pupils and/or their parents, and due to absences on account of illness and for other reasons, a total of 2,891 pupils in 145 classes were finally surveyed. This represented a response rate of 72.0 percent. The 
non-responses mostly involved pupils at lower-level type schools rather than those at mid-level and higher schools (Doering/Baier 2011, p. 58).

The pupils had an average age of 15.18 years. A little more than half of those surveyed were girls (51.3 percent). The vast majority were of German descent (84.2 percent); 16.8 percent had immigrant backgrounds, mostly from countries in the former Soviet Union. The share of immigrants in the ninth grade for the whole of Germany is 27.4 percent, serving to underline the particular social structure of the survey region. Pupils with immigrant backgrounds were defined as those who do not posses German citizenship or were not born in Germany or for whom one of these criteria applies to at least one biological parent.

\subsubsection{Measurement instruments}

Three concepts are specified in the hypotheses: Victimisation, morality and violent delinquency. These were operationalised as follows:

Victimisation: Two different forms of victimisation were surveyed. Respondents were first asked about experience of parental violence in childhood and then about other violent victimisation experience which could be categorised as criminal offences. This dual instrument had several advantages: On the one hand, early experience was compared with later experience. On the other, experience of events in a very specific context, the family, are placed in contrast with those largely expected in public spaces. ${ }^{1}$ With regard to parental violence, respondents were asked about their experience of six different types of parental behaviour. Pupils were asked to state whether, before they were twelve years old, their parents had shown behaviour towards them such a clip round the ear, rough handling/shoving, throwing an object at them, striking with an object, punching/kicking, or beating. The survey used the Strauß (1979) conflict-tactic scale. While the violent behaviour of the father and the mother were documented separately, the presentation in the following does not differentiate

1 Analyses show that only 12.7 percent of criminal violent victimisation occurs at home or with relatives; it occurs significantly more frequently in school/on the way to school, in the disco/youth centre, at bus stops/on public transport, on the sports field, etc. - meaning in places that can be described as 'public spaces' (Doering and Baier 2001, p. 64 f). This also means that an overlap exists, albeit a small one, between the victimisation variables. 
between violence exercised by the father and that exercised by the mother. Instead, the maximum value is used; this means that if a pupil experienced only paternal violence and was not exposed to violence from the mother, the answer for the father is taken into account. The frequency of each violent act was to be rated on a scale of ' $1=$ never' to ' $6=$ several times a week'. The first three types of behaviour were described as 'mild violence', the last three as 'severe violence'. Initially, a new maximum score was calculated for each of these two forms of violence. If a respondent had, for example, received a clip round the ear from the father and/or the mother, but had not been roughly handled/shoved, the answer regarding the clip around the ear determines the score on the index 'mild violence'. A delineation was only made in the end between pupils who had experienced violence and those who had not, because high frequencies of parental violence only featured on rare occasions. Finally, both types of violence were combined to form three groups of pupils: Those with no experience of violence, those who had at most experienced mild violence, and those who had (also) experienced severe violence.

Criminal acts of violent victimisation were surveyed by asking respondents about their experience of four offences: Assault ("someone deliberately hit you so hard that they injured you" - for example, a bleeding wound or a black eye), aggravated assault ("you were deliberately injured with a weapon or an object or several people deliberately hit you so hard that you were injured"), robbery ("someone used violence in snatching something from you or threatened you with violence while taking something from you, such as your bag or money") and extortion ("someone tried to make you give them money or things (say a jacket or a watch) and threatened you with violence if you refused to give them what they wanted"). The aim was to document the lifetime prevalence, with the adolescents only given the choice of 'yes' or 'no' answer. Given the description of the offences and the frequency distribution ${ }^{2}$, a differentiation was made between mild and serious offences (assault versus aggravated assault, robbery, and extortion), resulting in a three-part variable: Adolescents who have never experienced criminal violent victimisation, adolescents who

2 Assault were experienced by 20.4 percent of adolescents; the other offences by 5.0 percent at most. 
have at most experienced mild violence, and adolescents who have (also) experienced serious victimisation. ${ }^{3}$

Morality: In accordance with the cited definition of morality, it is necessary to delineate between the cognitive, emotional and motivational components. Three different measurement instruments are used. The cognitive component is measured via the centrality of moral traits. To measure moral centrality, the 'good-self assessment scale' (Arnold 1993, Barriga et al. 2001, Harter/Monsour 1992, Nunner-Winkler et al. 2006, Pratt et al. 1999, Pratt et al. 2003) was used in a shortened and adapted version. Pupils were asked to rate on a scale of ' $1=$ not important at all' to ' $4=$ extremely important' the importance they place on possessing four moral traits (fairness, honesty, willingness to help others, consideration of others) and four personal traits (popularity, sense of humour, athleticism, intelligence). Table 12.1 shows factor loadings and item item-total correlation for the items in question. The 'sense of humour' item shows a low factor loading and item Item-total correlation and is thus excluded from the analyses. The remaining items can be combined into two scales due to the good scale reliability. The correlation between the two scales is -.01 (not significant). The deciding factor is that in the analyses, it is not the scale values that are considered but the difference between the moral and personal traits. This is necessary, because the moral traits prove popular across the board and thus the difference between them and the personal traits is the deciding factor. A positive difference indicates a higher level of importance is placed on moral compared with personal traits. A negative difference points, by way of contrast, to personal traits being seen as more important. The average of the difference variable 'centrality of moral traits' is 0.84 (standard deviation: 0.77 ); overall, 12.5 percent of respondents achieved a negative difference rating, while 83.5 percent achieved a positive difference rating (at 4.0 percent, the difference in zero).

The emotional components of morality were identified via empathy using a reduced, four-item instrument based on Stadler et al. (2004; see Table 12.2). Respondents were asked to rate their answers on a scale from ' 1 $=$ does not apply' to ' $4=$ fully applies'. The mean values thus show that most pupils are empathetic. The scale can be considered reliable. The overall mean is 2.96 (standard deviation: 0.63 ).

3 A positive relationship exists between experience of parental violence and criminal violent victimisation (Spearman's Rho $=.27, \mathrm{p}<.001$ ). 
Table 12.1 Statistics for items measuring centrality of moral traits

\begin{tabular}{|c|c|c|c|c|c|c|c|}
\hline & & Mean & $\begin{array}{c}\text { Standard de- } \\
\text { viation }\end{array}$ & Factor $1^{\mathrm{a}}$ & $\begin{array}{c}\text { Factor } \\
2\end{array}$ & $\begin{array}{l}\text { Item-total } \\
\text { correlation }\end{array}$ & $\begin{array}{c}\text { Cronbach's } \\
\text { alpha }\end{array}$ \\
\hline \multirow{4}{*}{$\begin{array}{l}\text { Moral } \\
\text { values }\end{array}$} & Fair & 3.51 & 0.57 & .68 & & .43 & \multirow{4}{*}{.68} \\
\hline & Honest & 3.72 & 0.50 & .62 & & .37 & \\
\hline & Helpful & 3.40 & 0.59 & .75 & & .52 & \\
\hline & Considerate & 3.33 & 0.61 & .79 & & .55 & \\
\hline \multirow{4}{*}{ Personal } & Popular & 2.52 & 0.82 & & .74 & .43 & \multirow{4}{*}{$.64^{\mathrm{b}}$} \\
\hline & Sense of humour & 3.32 & 0.66 & & .34 & .18 & \\
\hline & Athletic & 2.68 & 0.94 & & .77 & .48 & \\
\hline & Intelligent & 2.73 & 0.80 & & .73 & .42 & \\
\hline
\end{tabular}

${ }^{a}$ Factor loading in an explorative factor analysis (principal component analysis) with varimax rotation (only loadings $>.30$ are shown)

b reliability without 'sense of humour'

\section{Table 12.2 Statistics for items measuring empathy}

\begin{tabular}{|c|c|c|c|c|}
\hline & Mean & $\begin{array}{l}\text { Standard } \\
\text { deviation }\end{array}$ & $\begin{array}{c}\text { Item-total } \\
\text { correlation }\end{array}$ & $\begin{array}{c}\text { Cronbach's } \\
\text { alpha }\end{array}$ \\
\hline I bothers me when I see someone being made fun of. & 2.82 & 0.76 & .66 & \multirow{4}{*}{.83} \\
\hline I find it very upsetting when I see someone cry. & 2.94 & 0.82 & .63 & \\
\hline I feel sorry for pupils who are often teased. & 3.09 & 0.78 & .71 & \\
\hline I often feel for those who are worse off than myself. & 2.99 & 0.75 & .61 & \\
\hline
\end{tabular}

The motivational component of morality is identified using a measure to analyse 'moral motivation'. This is based on Nunner-Winkler et al. (2006), and attempts to illustrate motivation based on 'hypothetical decisions on how to act and potential emotions in moral conflicts' (p. 66). In the use of moral conflict, unlike in the case of moral dilemma, it is not two moral values that stand in contradiction to one another, but a moral value and a personal need. The construction of moral conflict follows three criteria: Firstly, pupils need to be familiar with the structure of the described situations, and secondly, they need to be readily able understand the moral dimension. Thirdly, it should not be too difficult for them to make immoral decisions. The following conflict (bike conflict) was presented using the following wording: "Imagine you offered your bike for sale. You want to sell it for 400 Euro. A pupil is interested. He bargains with you and you agree on 320 Euro. Then he says: 'Sorry, I don't have the money on me; I'll quickly run home to get it. I'll be back in half an hour.' You say: 
'Agreed, I'll wait for you.' Shortly after he is gone, another customer shows up who is willing to pay the full price." The pupils are then asked to state what they would do in this situation, how they would justify their actions, how they would feel at the time, and why they would feel that way. The open answer format was chosen because what are known as 'production measures' rather than 'recognition measures' can reduce the degree of socially desired answers (Elm/Weber 1994).

The open answers given by the pupils were coded and evaluated using an evaluation strategy based on Nunner-Winkler et al. (2006) and Malti and Buchmann (2010). Because, for the first time, moral conflict was used not in a verbal interview but in a written questionnaire, a manipulation check was applied to verify that the pupils had understood the conflict: 2.2 percent of them incorrectly marked the manipulation check and were excluded from subsequent analyses. The collected data were coded by two trained students. The coding was done using an inductive categorisation system. The system and its reliability were tested on 9.5 percent of the cases prior to application. The interrater reliability (Cohen's Kappa) was over .70 for all categories, which is seen as a good consensus (Bortz/ Döring 2005, p. 277). For the ensuing analyses, a global rating was formed from the decisions, justifications and emotions: On the one hand, the 'victimiser' category, meaning those who sold the bike to the second customer and felt good or bad in doing so, and who gave pragmatic reasons for the decision; on the other, the 'moralists' who sold to the bike to the first customer, had either positive or negative feelings about it, and gave moral-based reasons for their decision. Some 47.0 percent of the pupils belonged to the victimizer group, and 53.0 percent to the moralists. In contrast to the measurement instruments presented thus far, the number of missing values is very high (21.7 percent of all respondents). This can be explained by the open answer format (with a higher number of uncodable entries) and the use of the manipulation check.

The three components of morality are not mutually exclusive, while the correlations only lie in the middle range, thus confirming that different dimensions of morality are represented. The correlations (Pearson's r) are . $29(\mathrm{p}<.001)$ between moral centrality and empathy, $.20(\mathrm{p}<.001)$ between moral centrality and moral motivation and $.18(\mathrm{p}<.001)$ between empathy and moral motivation.

Violent delinquency: In contrast to criminal victimisation, respondents were asked whether they had committed four types of violent acts (assault, aggravated assault, robbery, and extortion). Rather than lifetime preva- 
lence, the analysis looked at twelve-month prevalence. This shows the proportion of adolescents who had committed at least one violent act in the past twelve months. Twelve-month prevalence is used to bring out a causal structure: Parental violence and victimisation in the form of violent criminal offences in respondents' lives to date had largely occurred prior to the past twelve months. In the case of parental violence, this is ensured by the wording of the question ('before you were 12 years old'); with the other three types of victimisation, it can be assumed because respondents' average age at first victimisation involving the four offences is 11.3 years, meaning long before their fifteenth birthday.

\subsection{Findings}

Table 12.3 contains descriptive statistics on the model variables used, some of which have been mentioned in the preceding section. With the exception of experience of parental violence, significant gender differences are evident, making it necessary to take account of the gender variables in multivariate analyses. Boys have significantly more frequent experience of violent criminal offences, both as victims and as perpetrators. Girls, by contrast, show a significantly higher mean for the three dimensions of morality. Overall, it was found that 40.2 percent of respondents experienced violence during childhood, with one in four experiencing serious violence. 24.3 percent of respondents reported experience of violent criminal offences as victims ( 9.6 percent serious violence). Six percent of the adolescents surveyed said they had committed a violent offence in the past twelve months. ${ }^{4}$

The assumptions in Hypotheses 1, 1a and $1 \mathrm{~b}$ were tested for the three components by linear regression. The findings are shown in Table 12.4. To verify whether experience of serious violence has a greater influence than that of mild violence, adolescents with experience of mild violence form the reference group; if Hypothesis 1a holds true, adolescents with no experience of violence should demonstrate significantly higher morality, while those with experience of serious violence should show significantly lower morality. In order to analyse whether the correlations are the same for both

4 The mean for this variable and for the moral motivation variable can be seen as a percentage because the two variables are dichotomous and can be treated as interval-scaled variables. 
Table 12.3 Descriptive statistics of the survey variables by gender

\begin{tabular}{|c|c|c|c|c|c|c|}
\hline & & $\mathbf{N}$ & $\begin{array}{c}\% / \text { mean (stan- } \\
\text { dard } \\
\text { deviation) }\end{array}$ & $\begin{array}{c}\text { Boys } \\
(\% / \text { mean })\end{array}$ & $\begin{array}{c}\text { Girls } \\
(\% / \text { mean })\end{array}$ & $\begin{array}{l}\text { Cramer's } \\
\text { V/t-value }\end{array}$ \\
\hline \multirow{3}{*}{$\begin{array}{l}\text { Parental violence in } \\
\text { childhood }\end{array}$} & Never & \multirow{3}{*}{2836} & 59.8 & 58.1 & 61.3 & \multirow{3}{*}{.034} \\
\hline & Mild & & 29.6 & 31.1 & 28.2 & \\
\hline & Serious & & 10.6 & 10.8 & 10.4 & \\
\hline \multirow{3}{*}{$\begin{array}{l}\text { Victimisation via violent } \\
\text { criminal offences }\end{array}$} & Never & \multirow{3}{*}{2857} & 75.7 & 68.3 & 82.8 & \multirow{3}{*}{$.169^{* * *}$} \\
\hline & Mild & & 14.7 & 19.2 & 10.5 & \\
\hline & Serious & & 9.6 & 12.5 & 6.8 & \\
\hline Moral centrality & & 2875 & $0.84(0.77)$ & 0.63 & 1.05 & $-15.278^{* * *}$ \\
\hline Empathy & & 2870 & $2.96(0.63)$ & 2.69 & 3.22 & $-24.456 * * *$ \\
\hline Moral motivation & & 2265 & $1.53(0.50)$ & 1.44 & 1.61 & $-8.004 * * *$ \\
\hline Violent delinquency & & 2791 & $0.06(0.24)$ & 0.10 & 0.03 & $7.894 * * *$ \\
\hline
\end{tabular}

$* \mathrm{p}<.05, * * \mathrm{p}<.01, * * * \mathrm{p}<.001$

genders, gender and the interaction variables between gender and experience of violence are also specified; these should have no significance if Hypothesis $1 \mathrm{~b}$ holds true. ${ }^{5}$

The models show that, when controlled for victimisation experience, female respondents show significantly higher morality than male respondents, with the strongest effect in relation to empathy. Victimisation experience, almost across the board, has no influence on respondents' level of morality. Experience of criminal victimisation plays no role at all, while experience of parental violence is at least seen to have a significant link with moral motivation: Adolescents who were exposed to serious parental violence display lower levels of moral motivation than those who experience mild or no parental violence. Of the twelve specified interaction effects, nine are not significant. The effect for the remaining three significant effects is more or less negligible. Because the main effects are not significant, the interaction effects should not be looked at in any detail. There is evidence that the influence of the experience of violence on moral motivation tends to be greater in female respondents than in male respondents. ${ }^{6}$

5 To avoid multicollinearity when introducing interaction variables, all variables were mean-centered before being multiplied (cf. Jaccard/Turrisi 2003). 
Table 12.4 Influencing factors of morality (OLS regressions; coefficient: Beta)

\begin{tabular}{|c|c|c|c|}
\hline & $\begin{array}{c}\text { Model: Moral } \\
\text { centrality }\end{array}$ & $\begin{array}{c}\text { Model: } \\
\text { Empathy }\end{array}$ & $\begin{array}{l}\text { Model: Moral } \\
\text { motivation }\end{array}$ \\
\hline Gender: Female (a) & $.27 * * *$ & $.42 * * *$ & $.15 * * *$ \\
\hline Parental violence: Mild & Reference & Reference & Reference \\
\hline Parental violence: None (b) & .03 & -.01 & .04 \\
\hline Parental violence: Serious (c) & -.03 & .01 & $-.05 *$ \\
\hline Criminal violent victimisation experience: Mild & Reference & Reference & Reference \\
\hline Criminal violent victimisation experience: Never (d) & -.01 & .01 & .04 \\
\hline Criminal violent victimisation experience: Serious (e) & -.02 & .02 & .01 \\
\hline Interaction $\mathrm{a} * \mathrm{~b}$ & .01 & $.05 *$ & $.06 *$ \\
\hline Interaction a $* \mathrm{c}$ & .03 & .03 & -.01 \\
\hline Interaction $\mathrm{a} * \mathrm{~d}$ & .01 & -.01 & -.02 \\
\hline Interaction a $* \mathrm{e}$ & $-.05 *$ & .00 & -.03 \\
\hline Number of cases & 2787 & 2784 & 2208 \\
\hline $\mathbf{R}^{2}$ & .076 & .177 & .035 \\
\hline
\end{tabular}

$* \mathrm{p}<.05, * * \mathrm{p}<.01, * * * \mathrm{p}<.001$

Because victimisation experience is only marginally linked with the various components of morality, there is no need to test Hypothesis 2a. The findings of the test are nonetheless shown in Table 12.5. Binary logistic regression analyses were conducted using violent delinquency (in the last twelve months) as the dependent variable. The first model confirms a significant relationship between experience of violent victimisation and violent delinquency: Adolescents with no experience of parental violence and no experience of criminal violent victimisation are significantly less likely to commit violent offences than those with experience of mild violence. Additionally, at least when it comes to parental violence, there is evidence that adolescents with experience of serious violence are significantly more

6 This can be illustrated by the example of moral motivation and parental violence: The means for boys are 1.45 (no parental violence), 1.45 (mild violence) and 1.39 (serious violence), with the differences not significant $(\mathrm{F}=0.723, \mathrm{p}>.05)$. For girls, by contrast, there are significant differences between the three groups (means: 1.66, 1.56 and 1.47; $\mathrm{F}=10.510, \mathrm{p}<.001$ ). Post-hoc testing (Scheffé test) shows that the group with no experience of violence differs significantly from the other two groups $(\mathrm{p}<.01)$. 
likely to commit violent offences than those with experience of mild violence. Additionally, fewer girls than boys commit violent offences.

The second model takes in the morality variables. Little change is seen regarding the coefficients of the victimisation variables, meaning that no mediation occurs. Given that the coefficients hardly change, a mediation test was not performed. Of the morality variables, empathy and motivation prove to be significant. Greater empathy and greater moral motivation reduce the risk of violent delinquency. Moral centrality has, by way of contrast, no influence on violent delinquency. It is interesting that with the inclusion of the morality variables, the influence of gender drops significantly. That female adolescents commit fewer violent acts than male adolescents is thus partly due to their higher morality.

Table 12.5 Influencing factors of violent delinquency (binary logistic regression; coefficient: $\operatorname{Exp}(B))$

\begin{tabular}{|c|c|c|}
\hline & Model I & Model II \\
\hline Gender: Female & $0.302 * * *$ & $0.497 * *$ \\
\hline Parental violence: Mild & Reference & Reference \\
\hline Parental violence: None & $0.643 *$ & $0.610 *$ \\
\hline Parental violence: None & $1.925 * *$ & $1.898 *$ \\
\hline Criminal violent victimisation: Mild & Reference & Reference \\
\hline Criminal violent victimisation: Never & $0.184 * * *$ & $0.188 * * *$ \\
\hline Criminal violent victimisation: Serious & 0.884 & 0.871 \\
\hline Moral centrality & & 1.059 \\
\hline Empathy & & $0.467 * * *$ \\
\hline Moral motivation & & $0.525 * *$ \\
\hline Number of Cases & 2154 & 2154 \\
\hline Nagelkerkes $\mathbf{R}^{2}$ & .203 & .249 \\
\hline
\end{tabular}

$* \mathrm{p}<.05, * * \mathrm{p}<.01, * * * \mathrm{p}<.001$

Supplementary analysis: Victimisation and other personality traits

The findings presented above were unable to confirm the central hypotheses. In discussing these findings, it is possible to focus either on substantive aspects or on distinguishing features of the specific dataset. As noted when describing the sample, the area where the survey was conducted offers more intact conditions for growing up compared with the national av- 
erage. The sample may display too little variance in the experience of violent victimisation for any stable relationships to be identified - especially when it comes to serious violence. Before non-confirmation of the hypotheses is put down to the sample, however, it would appear useful to see if other personality factors that attract greater focus in criminological research similarly lack any systematic relationship with victimisation experience. If not, then the hypotheses should be subjected to substantive discussion.

Table 12.6 Statistics for items measuring risk-seeking and affinity to violence

\begin{tabular}{|c|c|c|c|c|}
\hline & Mean & $\begin{array}{l}\text { Standard } \\
\text { deviation }\end{array}$ & $\begin{array}{l}\text { Item-total } \\
\text { correlation }\end{array}$ & $\begin{array}{c}\text { Cronbach's } \\
\text { alpha }\end{array}$ \\
\hline I like to test my limits by doing something dangerous. & 2.19 & 0.91 & .75 & \multirow{4}{*}{.90} \\
\hline $\begin{array}{l}\text { I find it exciting sometimes to do things that are potential- } \\
\text { ly dangerous. }\end{array}$ & 2.19 & 0.95 & .79 & \\
\hline Excitement and adventure are more important than safety. & 2.12 & 0.88 & .75 & \\
\hline It's fun to take risks. & 2.34 & 0.94 & .80 & \\
\hline Scale "risk-seeking" & \multicolumn{4}{|c|}{2.21 (Boys: 2.44, Girls: 1.99, $\mathrm{t}=15.222^{* * *}$ ) } \\
\hline $\begin{array}{l}\text { The man is the head of the family. Women and children } \\
\text { have to do as he says. }\end{array}$ & 1.83 & 0.85 & .36 & \multirow{8}{*}{.74} \\
\hline If a woman betrays her husband, he's allowed to hit her. & 1.12 & 0.45 & .34 & \\
\hline $\begin{array}{l}\text { A man should be ready and willing to use violence to de- } \\
\text { fend his wife and children. }\end{array}$ & 2.69 & 1.02 & .43 & \\
\hline $\begin{array}{l}\text { A man who isn't willing to use violence when someone } \\
\text { insults him is a weakling. }\end{array}$ & 1.56 & 0.84 & .54 & \\
\hline $\begin{array}{l}\text { The man is the head of the family and is allowed to use } \\
\text { violence when necessary. }\end{array}$ & 1.27 & 0.61 & .41 & \\
\hline $\begin{array}{l}\text { Men should be allowed to own firearms in order to protect } \\
\text { their families and property. }\end{array}$ & 1.60 & 0.89 & .48 & \\
\hline $\begin{array}{l}\text { A real man is willing to hit out if someone speaks badly } \\
\text { about his family. }\end{array}$ & 1.63 & 0.87 & .59 & \\
\hline A real man is strong and protects his family. & 3.01 & 0.90 & .35 & \\
\hline Scale "affinity to violence" & \multicolumn{4}{|c|}{1.84 (Boys: 2.00 , Girls: $1.68, t=18.766^{* * *}$ ) } \\
\hline
\end{tabular}

$* \mathrm{p}<.05, * * \mathrm{p}<.01, * * * \mathrm{p}<.001$

Two additional personality factors were investigated in the survey: Riskseeking as a dimension of low self-control, and affinity to violence. For both personality traits, other studies report correlations with experience of parental violence and violent delinquency (among others Baier at al. 2006, p. $148 \mathrm{ff}$ and p. $156 \mathrm{ff}$, Fuchs et al. 2005, p. $145 \mathrm{ff}$ and $314 \mathrm{ff}$, Wetzels et al. 2001, p. 253 ff). Risk-seeking was documented using four items. These are shown in Table 12.6 and are based on a proposal by Grasmick et al. 
(1993). When investigating affinity to violence, an eight-item scale was used which measures physical violence, to which men are far more prone (see Enzmann et al. 2004). Both scales show adequate reliability. Male adolescents achieve significantly higher mean scores on both scales. ${ }^{7}$

Analyzing victimisation experience as an influencing factor of both personality traits using OLS regressions produces the findings shown in Table 12.7. For affinity to violence, the coefficients fully match expectations: Adolescents with no experience of parental violence and/or with no experience of criminal violent victimisation demonstrate significantly lower affinity than those with experience of mild violence; school students with experience of serious violence also tend to have a greater affinity to violence than those with experience of mild violence. When it comes to riskseeking, there is evidence that the dividing line runs between the group without and the group with experience of violence, meaning that the degree of violence is less relevant. Adolescents with no experience of violence demonstrate significantly lower risk-seeking than those with experience of mild or serious violence.

\section{Table 12.7 Influencing factors of affinity to violence and risk-seeking} (OLS regressions; coefficient: Beta).

\begin{tabular}{l|c|c}
\hline & $\begin{array}{c}\text { Model: Affinity } \\
\text { to violence }\end{array}$ & $\begin{array}{c}\text { Model: Risk- } \\
\text { seeking }\end{array}$ \\
\hline Gender: Female & $-.31^{* * *}$ & $-.25{ }^{* * *}$ \\
\hline Parental violence: Mild & Reference & Reference \\
\hline Parental violence: None & $-.10 * * *$ & $-.06 * *$ \\
\hdashline Parental violence: Serious & $.05 * *$ & .02 \\
\hline Criminal violent victimisation: Mild & Reference & Reference \\
Criminal violent victimisation: Never & $-.08 * *$ & $-.12 * * * \ldots$ \\
Criminal violent victimisation: Serious & $.04 *$ & .02 \\
\hline Number of cases & $\mathbf{2 7 8 3}$ & $\mathbf{2 7 7 7}$ \\
\hline $\mathbf{R}^{2}$ &. $\mathbf{1 4 7}$ &. $\mathbf{1 0 2}$ \\
\hline
\end{tabular}

$* \mathrm{p}<.05, * * \mathrm{p}<.01, * * * \mathrm{p}<.001$

7 The correlations between the personality traits and the moral dimension are moderate but all significant $(\mathrm{p}<.001)$. The correlation with affinity to violence is -.24 for moral centrality, -.27 for empathy and -.22 for motivation. The correlations for riskseeking are -.22 (centrality), -.21 (empathy) and -.17 (motivation). 
The personality factors are significant influencing variables of violent delinquency (Table 12.8). Adolescents who accept violence and are prone to take risks show a significantly higher risk of violent delinquency. To a certain extent, the personality factors also mediate the influence of victimisation experience. This is especially evident for the group of adolescents with experience of serious parental violence. In Model I, these show a significantly greater risk of violence than those with experience of mild violence; in Model II this significant effect disappears. Full mediation of the influence of violent experience, however, does not occur. Experience of violence can thus affect a person's affinity to violence independent of the associated changes in the personality structures.

Table 12.8 Influencing factors of violent delinquency (binary logistic regressions; coefficient: $\operatorname{Exp}(B))$

\begin{tabular}{|c|c|c|}
\hline & Model I & Model II \\
\hline Gender: Female & $0.295 * * *$ & $0.547 * *$ \\
\hline Parental violence: Mild & Reference & Reference \\
\hline Parental violence: None & $0.552 * *$ & $0.579^{* *}$ \\
\hline Parental violence: Serious & $1.645 *$ & 1.408 \\
\hline Criminal violent victimisation: Mild & Reference & Reference \\
\hline Criminal violent victimisation: Never & $0.194 * * *$ & $0.225 * * *$ \\
\hline Criminal violent victimisation: Serious & 0.639 & 0.817 \\
\hline Affinity to violence & & $2.682 * * *$ \\
\hline Risk-seeking & & $1.805 * * *$ \\
\hline Number of cases & 2697 & 2697 \\
\hline Nagelkerkes $\mathbf{R}^{2}$ & .198 & .272 \\
\hline
\end{tabular}

$* \mathrm{p}<.05, * * \mathrm{p}<.01, * * * \mathrm{p}<.001$

\subsection{Discussion}

Based on the results for affinity to violence and risk-seeking, the findings relating to morality cannot be ascribed solely to specific characteristics of the sample. In relation to established concepts in criminological research, expectations regarding the influence of violent victimisation are confirmed. Neither the sample nor the operationalization used in relation to morality should be criticised because established methods were applied that demonstrate adequate reliability. The constructs can also be assumed 
to have adequate validity from their moderate inter-correlation and from their expected negative correlation with delinquent behaviour. In the following, therefore, the findings will be discussed substantively in relation to the presented hypotheses.

Hypothesis 1 assumes that victims of violence have lower morality than non-victims. This is not confirmed in a multidimensional analysis of morality (cognitive, emotional and motivational). There is only one point where serious parental violence is shown to have a significant effect on moral motivation. In contrast, multiple significant correlations are evident between victimisation and other personality traits. Socialisation conditions relating to morality differ in some ways to socialisation conditions relating to other personality traits. Negative experiences foster the development of negative traits; they do not, however, prevent the development of positive traits to the same degree. In terms of the social information processing model (Crick/Dodge 1994), this means that the data base and in particular adherence to/knowledge of social rules are not influenced by victimisation. A lack of negative experience is thus not sufficient to foster positive personality traits. Resilience factors - which the findings on influencing factors of violent delinquency show to include morality - are not fostered by the absence of violent experience. The findings thus indicate that in order to explain resilience factors, it is necessary to develop specific models and to subject them to empirical study; it is not enough to merely investigate the generic risk factors of delinquent behaviour and its predictors. Resilience factors are no doubt also to be found in children's and adolescents' key socialisation areas of family, school and friends.

Because Hypothesis 1 was refused, Hypotheses 1a and $1 \mathrm{~b}$ must also go unconfirmed. The degree of violence experienced adds nothing to the explanation of morality. Of more importance is whether or not an individual has experienced violence; this also applies in respect of violent delinquency. Recurrence of violence was not analysed for. This is possibly more important than the degree of violence experienced. Given the low number of adolescents with multiple experience of violence, however, such a hypothesis cannot be tested at this point.

As victimisation has no significant influence on morality, there is no need to investigate its influence by gender. This was still done, however, although no major differences were found regarding the effect of victimisation. There is, however, evidence of a somewhat stronger effect for girls. This is also confirmed by the findings of another study on the influence of parental violence on violent behaviour (Baier 2011). Experience of 
parental violence has a potentially greater impact for girls because girls are generally more family orientated; they tend to seek more parental closeness and trust than boys. Experience of violence could thus lead to greater feelings of hurt, which is compensated by a range of different behaviours.

On the subject of gender, one finding was brought out for which no hypothesis was specified. In the sample, as in many other studies, it was confirmed that boys demonstrate violent behaviour more frequently than girls. A range of explanations can be put forward for this purpose (cf. Scheithauer 2003). The analyses show that morality is a central explanatory factor. Female respondents display greater empathy and greater moral motivation, which in turn significantly influences violent behaviour. Against this backdrop, studies that focus on the influencing factors of morality must thus attempt to identify factors that significantly differ between boys and girls.

Given the non-existent relationship between victimisation and morality, it is not possible to confirm Hypothesis $2 \mathrm{a}$ - of morality having a mediating effect with regard to violent delinquency. Only moral centrality shows no relationship with violent delinquency in the multivariate model. Moral cognitions do not, therefore, prevent an individual from engaging in violence. It is possible that people for whom fairness, helping others and so on is important, believe the use of violence is still appropriate and legitimate in specific situations. For people with great empathy, this is almost certainly not an option because the negative feelings experienced by a victim of violence lie at the centre of decisions to act. The in some respects differing impacts of the dimensions of morality make it necessary to give greater consideration to the relationship between cognitive, emotional and motivational components of morality. Are, for example, the cognitive and emotional dimensions predictors of the motivational dimension or are all three dimensions of equal weighting? This question can only be answered using longitudinal studies.

The findings also highlight a further research question. Up to now, it has been assumed that one reason why victimisation affects violent delinquency is a change in personality. At least for affinity to violence and riskseeking, this can be confirmed to a marginal extent. Victims and non-victims still differ from one another significantly in their risk of violence, when these factors are taken into account. This might of course be due to other personality factors not included here in the analysis. It is possible that the direct relationship can have other causes. More recent studies 
point, for example, to cerebral changes in individuals who have been subjected to violence (cf. Teicher et al. 2012). This suggests a need for research investigating the systematically different mediators for the relationship between victimisation and violent delinquency, and also looking at potentially recursive relationships.

\section{References}

Arnold, M. L. (1993). The Place of Morality in the Adolescent Self. Harvard University, Cambridge, MA: unpublished thesis.

Arsenio, W. F., Lemerise, E. A. (2001). Varieties of Childhood Bullying: Values, Emotion Processes, and Social Competence. Social Development, 10, 59-73.

Baier, D. (2011). Jugendgewalt und Geschlecht - Erkenntnisse aus Kriminalstatistik und Dunkelfelduntersuchungen. Zeitschrift für Jugendkriminalrecht und Jugendhilfe, 4/2011, 356-364.

Baier, D., Kemme, S., Hanslmaier, M., Doering, B., Rehbein, F. Pfeiffer, C. (2011). Kriminalitätsfurcht, Strafbedürfnisse und wahrgenommene Kriminalitätsentwicklung. Ergebnisse von bevölkerungsrepräsentativen Befragungen aus den Jahren 2004, 2006 und 2010. KFN: Forschungsbericht Nr. 117.

Baier, D., Pfeiffer, C. (2011). Wenn Opfer nicht zu Tätern werden. Beeinflussen Bedingungen der Schulklasse den Zusammenhang von innerfamiliären Gewalterfahrungen und eigener Gewalttäterschaft? Trauma und Gewalt, 5, 6-19.

Baier, D., Pfeiffer, C., Windzio, M., Rabold, S. (2006). Schülerbefragung 2005: Gewalterfahrungen, Schulabsentismus und Medienkonsum von Kindern und Jugendlichen. Abschlussbericht über eine repräsentative Befragung von Schülerinnen und Schülern der 4. und 9. Jahrgangsstufe. KFN.

Barriga, A. Q., Morrison, E. M., Liau, A. K., Gibbs, J. C. (2001). Moral Cognition: Explaining the Gender Difference in Antisocial Behavior. Merrill-Palmer Quarterly, 47, 532-562.

Bortz, J., Döring, N. (2005). Forschungsmethoden und Evaluation für Human- und Sozialwissenschaftler (4. Auflage). Berlin: Springer.

Braithwaite, J. (1989). Crime, Shame and Reintegration. Cambridge: Universtity Press.

Celikates, R., Gosepath, S. (2009). Philosophie der Moral. Texte von der Antike bis zur Gegenwart. Frankfurt am Main: Suhrkamp.

Crick, N. R., Dodge, K. A. (1994). A Review and Reformulation of Social-Information Processing Mechanisms in Children's Social Adjustment. Psychological Bulletin, 115, 74-101.

Dodge, K. A. (1980). Social Cognition and Child's Aggressive Behavior. Child Development, 51, 162-170.

Dodge, K. A. (1993). Social Cognitive Mechanisms in the Development of Conduct Disorder and Depression. Annual Review of Psychology, 44, 559-584. 
Dodge, K. A., Bates, J. E., Pettit, G. S. (1990). Mechanisms in the Cycle of Violence. Science, 250, 1678-1683.

Doering, B. (2013). The Development of Moral Identity and Moral Motivation in Childhood and Adolescence. In K. Heinrichs, F. Oser (Eds.), Theoretical Perspectives and Empirical Results on Moral Motivation. Rotterdam: Sense Publishers (in press).

Doering, B. (2013a). Die Bedeutung Moralischer Motivation bei der Erklärung delinquenten Verhaltens im Jugendalter (in press).

Doering, B., Baier, D. (2011). Jugendliche als Opfer und Täter von Gewalt im Landkreis Emsland. KFN-Forschungsbericht Nr. 113. Hannover: KFN.

Eisenberg, N. (2002). An Affective Response that Stems from the Apprehension or Comprehension of Another's Emotional State or Condition, and That is Similar to What the Other Person is Feeling or Would be Expected to Eeel. In R. J. Davidson, A. Harrington (Eds.), Empathy-related Emotional Responses, Altruism, and their Socialization (pp. 131-164). London: Oxford University Press.

Elm, D. R., Weber, J. (1994). Measuring Moral Judgement: The Moral Judgement Interview or the Defining Issue Test. Journal of Business Ethics, 13, 341-355.

Enzmann, D., Brettfeld, K., Wetzels, P. (2004). Männlichkeitsnormen und die Kultur der Ehre. In D. Oberwittler, S. Karstedt (Eds.), Soziologie der Kriminalität (pp. 240-263). Wiesbaden: VS Verlag für Sozialwissenschaften.

Fuchs, M., Lamnek, S., Luedtke, J., Baur, N. (2005). Gewalt an Schulen: 1994 - 1999 2004 (1. Auflage). Wiesbaden: Verlag für Sozialwissenschaften.

Grasmick, H.G., Tittle, C.R., Bursik, R.J., Arneklev, B.J. (1993). Testing the Core Empirical Implications of Gottfredson and Hirschi's General Theory of Crime. Journal of Research in Crime and Delinquency, 30, 5-29.

Harter, S., Monsour, A. (1992). Developmental Analysis of Conflict Caused by Opposing Attributes in the Adolescent Self-Portrait. Developmental Psychology, 28, 251-260.

Hosser, D., Beckurts, D. (2005). Empathie und Delinquenz. KFN-Forschungsbericht Nr. 96. Hannover: KFN.

Jaccard, J., Turrisi, R. (2003). Interaction Effects in Multiple Regression. Thousand Oaks: Sage.

Kahn, A. (1984). Victims of Violence: Final Report of APA Task Force of Victims of Crime and Violence Washington: American Psychological Association.

Krettenauer, T., Eichler, D. (2006). Adolescents' Self-attributed Moral Emotions Following a Moral Transgression: Relations With Delinquency, Confidence in Moral Judgment and Age. British Journal of Developmental Psychology, 24, 489-506.

Malti, T., Buchmann, M. (2010). Socialization and Individual Antecedents of Adolescents' and Young Adults' Moral Motivation. Journal of Youth and Adolescence, 39, 138-149.

Malti, T., Perren, S., Buchmann, M. (2010). Children's Peer Victimization, Empathy, and Emotional Symptoms. Child Psychiatry and Human Development, 41, 98-113.

Murray-Close, D., Crick, N. R., Galotti, K. M. (2006). Children's Moral Reasoning Regarding Physical and Relational Aggression. Social Development, 15, 345-372. 
North, C.S., Smith, E.M., Spitznagel, E.L. (1994). Post-traumatic Stress Disorder in Survivors of a Mass Shooting. American Journal of Psychiatry, 151, 82-88.

Nunner-Winkler, G. (1991). Weibliche Moral. Die Kontroverse um eine geschlechtsspezifische Ethik. Frankfurt am Main, New York: Campus.

Nunner-Winkler, G. (2008). Zur Entwicklung moralischer Motivation. In J. Schneider (Ed.), Entwicklung von der Kindheit bis zum Erwachsenenalter: Befunde der Münchner Längsschnittstudie LOGIK (pp. 103-123). Weinheim: Beltz.

Nunner-Winkler, G., Meyer-Nikele, M., Wohlrab, D. (2006). Integration durch Moral: Moralische Motivation und Ziviltugenden Jugendlicher. Wiesbaden: VS Verlag für Sozialwissenschaften.

Perry, D. G., Perry, L. C., Rasmussen, P. (1986). Cognitive Social Learning Mediators of Aggression. Child Development, 57, 700-711.

Pratt, M. W., Arnold, M. L., Pratt, A. T., Diessner, R. (1999). Predicting Adolescent Moral Reasoning from Family Climate: A Longitudinal Study. Journal of Early Adolescence, 19, 148-175.

Pratt, M. W., Hunsberger, B., Pancer, S. M., Alisat, S. (2003). A Longitudinal Analysis of Personal Values Socialization: Correlates of a Moral Self-ideal in Late Adolescence. Social Development, 12, 563-585.

Rest, J. R. (1983). Morality. In J. Flavell, E. Markman (Eds.), Handbook of Child Psychology: Vol.3. Cognitive Development (pp. 556-628). New York: Wiley.

Scheithauer, H. (2003). Aggressives Verhalten von Jungen und Mädchen. Göttingen: Hogrefe.

Slaby, R. G., Guerra, N. G. (1988). Cognitive Mediators of Aggression in Adolescent Offenders: 1. Assessment. Developmental Psychology, 24, 580-588.

Stadler, C., Janke, W., Schmeck, K. (2004). IVE - Inventar zur Erfassung von Impulsivität, Risikoverhalten und Empathie bei 9- bis 14jährigen Kindern. Göttingen: Hogrefe.

Stams, J. G., Brugman, D., Dekovic, M., Rosmalen, L., Laan, P., Gibbs, J. C. (2006). The Moral Judgment of Juvenile Delinquents: A Meta-analysis. Journal of Abnormal Child Psychology, 34, 697-713.

Staub, E. (1998). Breaking the Cycle of Genocidal Violence: Healing and Reconciliation. In J. Harvey (Ed.), Perspectives on Loss (pp. 231-238). Washington: Taylor and Francis.

Straus, M. A. (1979). Measuring Intrafamily Conflict and Violence: The Conflict Tactic Scales. Journal of Marriage and The Family, 41, 75-88.

Svensson, R., Pauwels, L., Weerman, F. M. (2010). Does the Effect of Self-control on Adolescent Offending Vary by Level of Morality? A Test in Three Countries. Criminal Justice and Behavior, 37, 732- 743.

Teicher, M.H., Anderson, C.M., Polcari, A. (2012). Childhood Maltreatment is Associated With Reduced Volume in the Hippocampal Subfields CA3, Dentate Gyrus, and Subiculum. Proseedings of the National Acadamy of Sciences of the United States of America, 109, E563-E572. 
Wetzels, P., Enzmann, D., Mecklenburg, E., Pfeiffer, C. (2001). Jugend und Gewalt. Eine repräsentative Dunkelfeldanalyse in München und acht anderen deutschen Städten. Baden-Baden: Nomos.

Wikström, P.-O. H. (2006). Individuals, Settings, and Acts of Crime: Situational Mechanisms and the Explanation of Crime. In P.-O. H. Wikström, R. J. Sampson (Eds.), The Explanation of Crime: Context, Mechanisms and Development (pp. 61-107). Cambridge: University Press.

Wikström, P.-O. H. (2009). Crime Propensity, Criminogenic Exposure and Crime Involvement in Early to Mid Adolescence. Monatsschrift für Kriminologie und Strafrechtsreform, 92, 253-266.

Wikström, P.-O. H., Ceccato, V., Hardie, B., Treiber, K. (2010). Activity Fields and the Dynamics of Crime. Advancing Knowledge About the Role of the Environment in Crime Causation. Journal of Quantitative Criminology, 26, 55-87.

Wikström, P.-O. H., Treiber, K. H. (2009). Violence as Situational Action. International Journal of Conflict and Violence, 3, 75-96.

Wilmers, N., Enzmann, D., Schaefer, D., Herbers, K., Greve, W., Wetzels, P. (2002). Jugendliche in Deutschland zur Jahrtausendwende: Gefährlich oder gefährdet? Baden-Baden: Nomos. 